\title{
Qinghai and the Emergence of the West: Nationalities, Communal Interaction and National Integration*
}

\author{
David S. G. Goodman
}

ABSTRACT Qinghai is one of China's poorest provincial-level jurisdictions, least internally integrated and least integrated with the rest of the People's Republic. Its social complexity and fragile environment repeatedly created significant political and economic problems during the first half-century of the PRC, which were then exacerbated by policies that rapidly proved over-simplistic and counter-productive. Since January 2000 the PRC government's new policy initiative to develop the Western Region - the call to "Open Up the West" - has provided the provincial leadership with the opportunity to resolve some of the province's long-term difficulties through adopting markedly different perspectives on development. A more gradual approach has emerged, concentrating on the development of the province's infrastructure and environmental sustainability. Nevertheless, there remains a danger that in concentrating on economic solutions to the province's problems its inherent political, social and cultural contestations may be ignored to the detriment of the leadership's wider goals.

During the 1980s and 1990s Qinghai achieved the dubious distinction of becoming the provincial-level jurisdiction with the worst economic performance in the People's Republic of China (PRC). ${ }^{1}$ In 1978 Qinghai had been a wealthy (in relative terms) middle-income province, with annual GDP per capita well in excess of the national average (112.9 per cent). By 1994 it had become one of the lowest income provincial-level jurisdictions, with just over two-thirds of the national average (68.8 per cent). ${ }^{2}$ Economic growth was even slower for the two-thirds of the provincial population - 5.23 million people in 2001 - who lived in rural areas and by 1999, 39 of Qinghai's 46 county-level jurisdictions had become officially classified as "poverty stricken" at national or provincial-level. ${ }^{3}$ Equally as dramatically, by the 1990 s the province's financial

\footnotetext{
* Research for this article was undertaken in Qinghai during 2001-2003 with the support of the Australian Research Council. The assistance of Guo Jing, Qinghai Nationalities Commission, Ma Chengjun, Qinghai Nationalities Institute, and Ma Jianzhong, Qinghai University is gratefully acknowledged. Neither they nor any of those interviewed in connection with this project is responsible for any of the views or comments expressed in this article.

1. Zhai Songtian (ed.), 2002 nian Qinghai jingji lanpishu jingji xingshi fence yu yuce (Qinghai 2002 Economic Blue Book Analysis of Economic Conditions and Forecast, 2002) (Xining: Qinghai renmin chubanshe, 2002), p. 312. According to official data, during 1978-94 Qinghai averaged 5\% growth per annum in real GDP per capita, compared to Tibet, the next worst, at $5.8 \%$.

2. Wang Shaoguang and Hu Angang The Political Economy of Uneven Development: The Case of China (Armonk, NY: M. E. Sharpe, 1999), pp. 49-52.

3. In general, unless otherwise indicated, statistics for Qinghai are taken from Qinghai tongji nianjian 2001 (Qinghai Statistical Yearbook 2001) (Beijing: Zhongguo tongji

(C) The China Quarterly, 2004
} 


\section{Map 1: Qinghai Province}

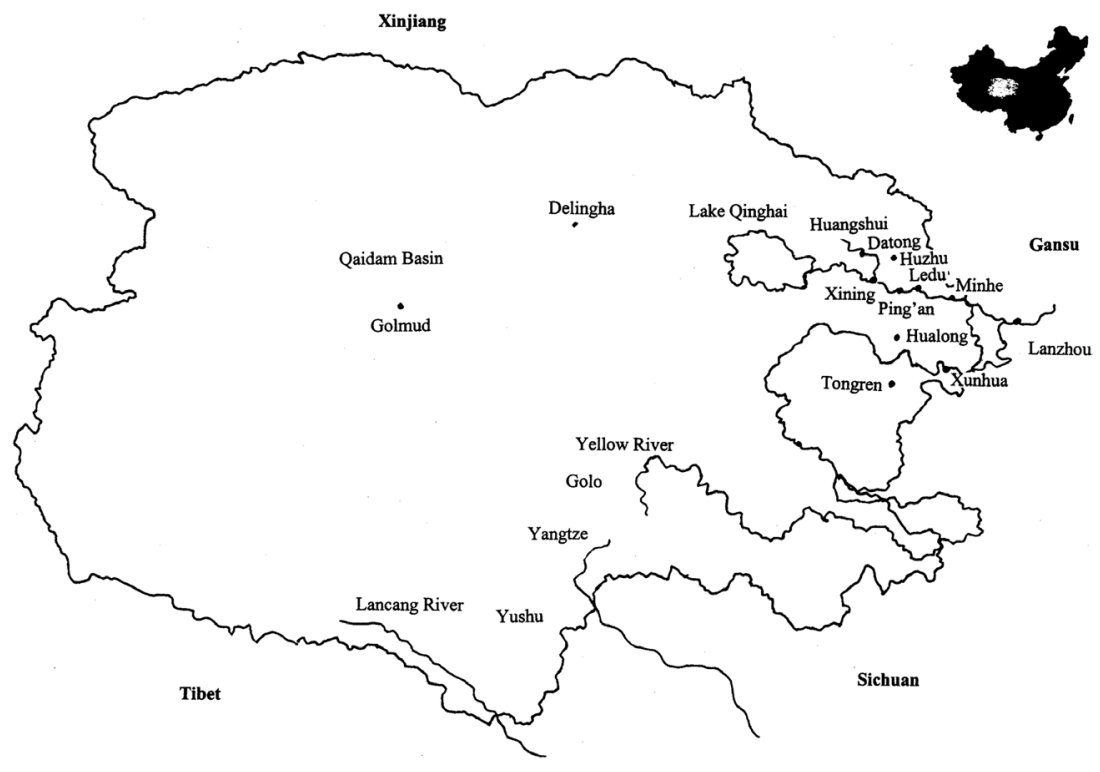

dependence on central government had doubled to four-fifths of budgetary expenditure. ${ }^{4}$

Qinghai's leadership has positively welcomed the campaign to "Open Up the West, not least because they see an opportunity to attempt a new approach to provincial development that might avoid previous problems. ${ }^{5}$ A long-term central economic problem has been the reliance on central government investment necessary for the development not only of the series of "Reform through Labour" camps for which the province has probably become most well-known, but also of its limited industrial base and communications infrastructure. In particular, from the mid-1950s on considerable efforts were put into the development of extraction industries (salts, oil, non-ferrous metals) in the Qaidam Basin, centred on Golmud and Delingha,as well as defence installations, such as the testing site for the PRC's first atomic and hydrogen bombs. ${ }^{6}$

footnote continued

chubanshe, 2001); comparative data from Zhongguo tongji nianjian 2001 (China Statistical Yearbook 2001) (Beijing: Zhongguo tongji chubanshe, 2001); historical data from Guojia tongjiju zonghesi (ed.), Quanguo ge sheng, zizhiqu, zhixiashi lishi tongji ziliao huibian (Collection of Historical Statistical Materials on every Province, Autonomous Region and Municipality) (Beijing: Zhongguo tongji chubanshe, 1990).

4. Peter Ferdinand, "The economic and financial dimension," in David S. G. Goodman (ed.), China's Regional Development (London: Routledge, 1989), p. 45.

5. For example, "Qinghai zenme yang, Qinghai zenme gan" ("What Qinghai is like and how it can speed up its development") in Qinghai ribao (Qinghai Daily), 13 August 2001, p. 13; and the statement by Zhao Leji, Governor of Qinghai on the opening of the provincial website, "As Qinghai advances in the world" at http://www.qh.gov.cn.

6. CCTV 11 July 2001 - http://www.cctv.com/english/news/20010711/50267.html. 
Past attempts at development had faltered through a variety of difficulties. In the 1950s, massive in-migration from other provinces and the opening of new agricultural land ended in human as well as economic disaster that underscored the fragility of the environment. In the second half of the 1960s and the first half of the 1970s the transfer of entire enterprises to Qinghai from elsewhere added a further financial burden rather than establishing a foundation for local economic growth. It also exposed both Qinghai's poor communications with the rest of the PRC and its weak internal integration, problems that similarly undermined the province's attempt to attract external investment with new PRC policies on openness and reform after 1980.

The provincial development strategy adopted during 2000 as part of the campaign to Open Up the West appears to have recognized the futility of past "quick fix" solutions to the province's development. In their place, it has opted for a more gradual approach that addresses three major issues: the need for environmental sustainability; greater internal integration of the province; and the development of better communications with the rest of the PRC. Necessarily much of the new strategy revolves around a series of infrastructure projects.

Even though it is clearly too soon to make a balanced assessment of its impact, the new development strategy certainly appears to present sounder opportunities for sustained socio-economic development than its predecessors. All the same, questions remain about the viability of an approach to development that regards the province's problems as capable of almost total economic solution. Since its establishment as a province of the Chinese state in 1928, Qinghai has been and remains socially complex with a high degree of political, social and cultural contestation amongst its local communities. In the first place, the provincial population is socially and culturally extremely diverse. Just over half are Han Chinese (53 per cent) divided almost equally between indigenous Han peoples and more recent migrants from the PRC. The remainder include a large number of minority nationalities, of whom the most significant are the Tibetans (22 per cent), Hui (16 per cent), Tu (4 per cent), Salar (2 per cent) and Mongols ( 2 per cent $)^{7}$

Moreover, within the province it is possible to identify different and sometimes competing ideas of Qinghai itself, only one of which is coterminous with the administrative area of the PRC. ${ }^{8}$ In addition to the contemporary party-state's view, there is Qinghai as Sino-centric Xining, the provincial capital and a long established border post of Empire; the agriculturally-settled north-east corner of the province (Haidong); the Tibetan highlands; the Tibetan and Mongolian grasslands; the more

7. "Quansheng zongrenkou wei 5181560 ren" ("The province's population reaches 5,181,560 people"), in Qinghai ribao, 28 April 2001, p. 1.

8. An obvious point in this context is that most places in Qinghai province have at least two, and sometimes more names, depending on culture and language. For example, Qinghai (in Chinese) is also known as Amdo (Tibetan) and Kokonor (Mongolian). Without wishing to privilege any specific culture and without intending to give offence to any other, all names will be presented in Chinese pinyin as a matter of convenience. 
recent (since the 1950s) Han Chinese migrant Golmud region; and the Islamic Hualong and Xunhua counties (known as "lianghua" - the "two Huas") the former heartland of Qinghai's famous Hui warlord Ma Bufang before 1949. The evidence would seem to suggest that without a provincial cultural development strategy, not least to explain to each of the local communities where they fit into the bigger picture, there may be severe challenges not only to the leadership's economic development goals, but also to social coherence in Qinghai.

\section{Physical and Social Environment}

Qinghai's physical and social geography explain many of the problems that have beset its development under the PRC. At 720,000 square kilometres the province has a relatively large land area (only the Xinjiang, Tibetan and Inner Mongolian Autonomous Regions are larger) that is in the main scarcely inhabited. Among provincial-level jurisdictions it has the third highest proportion of minority nationalities (46.5 per cent of the population) even though it is not a designated minority nationality autonomous region in the PRC's administrative system. The usual official explanation of this apparent anomaly is that there is a relatively large number of minority nationalities in the province -37 altogether - without any one being dominant. ${ }^{9}$ It would also seem likely that the inherent contestation of Qinghai was and remains a significant factor in that lack of autonomous regional status. A political and administrative compromise of a kind has been reached with the establishment of designated "autonomous" areas of self-government for minority nationalities at district and county levels. Of its eight district-level administrations only Xining city and Haidong (in the north-east of the province) are not designated autonomous areas. Within Xining, one of its three counties is an autonomous county; and within Haidong district, four of its six counties are autonomous counties. This situation has led to the description of Qinghai as "a non self governing area of self government." "

Qinghai is located on the north-east of the Tibetan-Qinghai Plateau with an average elevation in excess of 3,000 metres above sea level. The province is named after Lake Qinghai, China's biggest inland sea, and hosts the sources of three major rivers: the Yellow River, the Chang [Yangtze] and the Lancang River which becomes the Mekong. The province has three major geographical regions: the Qaidam Basin, west of Lake Qinghai and north of the Kunlun Mountains, which is an extremely arid area of salt marshes and desert, with the new (extraction industrybased) urban centre of Golmud; the sparsely inhabited mountainous plateau of Yushu and Guoluo (at an average in excess of 4,000 metres above sea-level); and the north-east corner around Xining, and between

9. Chen Yunfeng, Dangdai Zhongguo de Qinghai (Contemporary China's Qinghai) (Beijing: Dangdai Zhongguo chubanshe, 1991), Vol. 2, p. 316.

10. Interview with Doma Jiabu, Deputy Director, Qinghai Province Nationalities Affairs Commission, Xining, 31 July 2002. 
Xining and Gansu province to the east, centring on the valleys of the Huangshui and Huang [Yellow] Rivers. ${ }^{11}$

Elevation and climate mean that agriculture is largely confined to Qinghai's north-east corner, where 67.2 per cent of the provincial population live on 2.84 per cent of the land area. Moreover, even here, at an average elevation of just over 2,000 metres above sea level, the growing season is only about three months a year. While Xunhua county (on the Huang River and the border with Gansu) is able to achieve annual yields of 800 jin per $m u, 200$ or 300 jin per $m u$ each year at best is more usual in other counties. The capacity of the north-east corner, let alone the whole province, to support a large population has thus always been severely limited. Farming elsewhere is mainly livestock-based, concentrating on sheep, yaks and horses, and is often nomadic.

Elevation, climate and distance have also meant that communications have always been limited, both internally and with the rest of China. Outside the province's north-east corner travel has always been difficult, when possible at all, and many roads are not paved and not maintained. The main line of communication is the road that goes from Lanzhou (in neighbouring Gansu) to Xining; from Xining to Golmud (two days' travel even in 2003); and then on to Lhasa (four days).

Even within the north-east corner of the province where communications are better, they were limited for a long time. The Xining-Lanzhou railway line that connects Qinghai with the rest of the PRC was completed in 1959, and despite long-held plans has never been extended to Xinjiang, though a Xining-Golmud line was opened in 1979. A two-lane highway along the principal axis of communication within the north-east of the province was an early local project of the PRC, with a system of paved roads linking the adjoining counties. Even so, a road of any sort linking Xining with Xunhua and Hualong counties, to the south and east but still within Haidong district, was not completed until 1972. ${ }^{12}$ Under these circumstances it is perhaps little wonder that for others elsewhere in China Qinghai may be often incorrectly located as "west of Xinjiang," or confused with Qingdao, on the Shandong coast. ${ }^{13}$

Despite its location well within the territorial frontiers of the PRC, Qinghai remains essentially a border region. Before it became a province in 1928, all but the area around Xining was undisputedly outside the direct rule of the Chinese state and was part of Tibetan culture, with governance left to local clans and monasteries. The north-east corner of the later province was socially more contested, even though politically it was part of Gansu province. It had much in common with the southern part of that province in terms of the mix of cultures to be found there Han Chinese, Hui, Tibetan, Mongol, Salar - though Tibetan culture was

11. Qinghai sheng dili (Geography of Qinghai Province) (Xining: Qinghai renmin chubanshe, 1987); Qinghai shengqing (The Condition of Qinghai) (Xining: Qinghai renmin chubanshe, 1986), especially pp. 8ff.

12. Chen Yufeng, Contemporary China's Qinghai, Vol. 1, p. 397.

13. Xu Xiaoren, "Qinghai de yiyun" ("What Qinghai signifies") in Qinghai ribao, 23 December 2001, p. 3. 
somewhat stronger. Ta'ersi (Kumbum Monastery) just outside Xining is located where the founder of the Yellow Sect was born in the 14th century, and has been strongly associated with the Dalai Lamas since a Mongol Khan conferred the title on Sonam Gyatso in $1578 . .^{14}$ Xining itself was a long-established border town (back to at least the 12th century though claims are made to the sixth century ${ }^{15}$ ) at the crossroads between Mongol and Tibetan culture, north to south, and Han Chinese and Inner Asia Muslim culture, east to west.

These cultural interactions help explain the province's current social complexity. The Han Chinese are concentrated in Xining, the north-east counties of the province and the new urban centre of Golmud. The Tibetans are the overwhelming majority of the population outside the north-east corner, but there are even parts of Haidong where they constitute a significant minority of the population (a quarter, for example in Xunhua county). The Hui are concentrated in Xining and Haidong district in the valleys of the Huang and Huangshui Rivers and the hills in between, and particularly in Minhe, Hualong and Datong counties. The $\mathrm{Tu}$ and Salar nationalities originate in the province. The Tu are said to have settled in Huzhu county (to the north-east of Xining) with the Genghis Khan Mongols, and are Tibetan Buddhist having much in common with the Mongols. The Salar are a Turkic and Islamic people thought to have migrated from Central Asia to the banks of the Huang River in today's Xunhua county in about $1210 .^{16}$

While the less populous nationalities are relatively homogenous, the more numerous, especially the Han Chinese and the Tibetans, quite clearly are not. In broad terms the Han Chinese population are divided roughly equally between people whose families have been long settled in Xining and the north-eastern part of the province, and those who have migrated from the eastern provinces under one or other of the PRC's post-1949 campaigns. The former have a distinct local culture and language. ${ }^{17}$ They are predominantly Buddhist, and in rural areas have often adopted Hui and Tibetan lifestyles and customs. In contrast, the more recent migrants speak Modern Standard Chinese and have brought with them more of the culture of their various native places. Unlike the

14. $\mathrm{Pu}$ Wencheng, Gan-Qing zangzu fojiao siyuan (Tibetan Buddhist Monasteries of Gansu and Qinghai) (Xining: Qinghai renmin chubanshe, 1990, p. 141). Kumbum also became associated with the previous (tenth) Panchen Lama, who supported close relations with China generally before 1949 and with the CCP after 1949. He was a native of Xunhua county, also in the north-east corner of Qinghai province.

15. Cui Yonghong, Zhang Dezu, Du Changshun (eds.), Qinghai tongshi (A General History of Qinghai) (Xining: Qinghai renmin chubanshe, 1999), p. 197.

16. Guo Jing, Salazu jianshi (Introductory History of the Salar) (Xining: Qinghai renmin chubanshe, 1981); Li Xue Wei and Kevin Stuart, "The Xunhua Sala," Asian Folklore Studies, Vol. 49 (1990), pp. 39-52. "Tuzu” (“The Tu Nationality”), in Muchi Yundengjiacuo (ed.), Qinghai shaoshu minzu (Qinghai's Minority Nationalities) (Xining: Qinghai renmin chubanshe, 1995), p. 312.

17. Keith Dede, "Language contact, variation and change," $\mathrm{PhD}$ dissertation, University of Washington, 1999; Gao Fucheng, "Qinghai hanyu fangyan tansuo" ("An exploration of the Xining local variation of Chinese"), Qinghai minzu yanjiu (Nationalities Research in Qinghai), No. 3 (2002), p. 109. 
indigenous Han Chinese, a significant proportion of the more recent migrants live in Golmud and the surrounding area. Moreover, many of the more recent migrants have come to Qinghai but not with the intention of staying permanently, so that they might perhaps be better regarded (and often regard themselves only) as temporary "sojourners" rather than permanent migrants.

The Tibetans regard themselves as almost inherently divided by class, settlement, clan and level of integration into Chinese culture. ${ }^{18}$ Although the Tibetans of the interior, particularly Yushu and Guoluo, are essentially nomadic, there are both settled and agricultural Tibetans as well as nomadic pastoralists to be found throughout Qinghai. ${ }^{19}$ Assimilationalist policies of various kinds under both the Republic and the PRC before 1980 have meant that many Tibetans in Qinghai, especially but not exclusively those living in Xining and the north-east corner, do not speak any Tibetan, and may have only a rudimentary exposure to Tibetan culture. For those who are less integrated into Chinese culture, clan affiliation probably remains the most important determination of social action. ${ }^{20}$ Moreover, despite the relationship between Kumbum and Lhasa, and the current Dalai Lama being a native of Ping' an county (just east of Xining), Tibetans in Qinghai have long regarded themselves as both socially and politically separate from those in Central Tibet. ${ }^{21}$ In particular, the Qinghai region has a reputation for producing the leading Tibetan intellectuals and artists. Qinghai Tibetans readily acknowledge, and to a certain extent celebrate, that after the end of the Tibetan (Tubo) Empire in the ninth century they were never again "ruled by any one leader as a united people," and certainly not under Lhasa's control. ${ }^{22}$ Unsurprisingly, this perspective towards Tibetan Qinghai is not always shared in Lhasa or by exiled Tibetans. ${ }^{23}$

\section{Provincial Development}

As might be expected in a border region, the area that is now Qinghai has seen a fairly constant contest for political and cultural space. Sometimes this has resulted in open conflict, sometimes co-operation, and sometimes integration among the differing peoples and cultures of the region. Certainly contestation lay at the heart of the province's establishment and early development. While the establishment of Qinghai as a province in 1928 resulted in part from considerations of Republican Era

18. Muchi Yundengjiacuo, Qinghai's Minority Nationalities, p. 187.

19. Qinghai sheng renkou pucha bangongshe (ed.), Qinghai Zangzu renkou (Qinghai's Tibetan Population) (Beijing: Zhongguo tongji chubanshe, 1994), p. 23.

20. Li Zonghua and Li Yanqi, Anduo zangzu shilüe (Brief History of the Tibetans of Amdo) (Xining: Qinghai minzu chubanshe, 1992).

21. A Doak Barnett, China's Far West: Four Decades of Change (Boulder: Westview, 1993), p. 290.

22. Samten G Karmay "Amdo, one of the three traditional provinces of Tibet," Lungta, No. 2 (1994): The Amnye Machen Range - Ancestor of the Tibetans, p. 3.

23. Tsering Shakya, The Dragon in the Land of Snows: A History of Modern Tibet Since 1947 (London: Penguin, 1999). 
politics that were unrelated to matters on the ground in the region, the pressure for provincial status also came from local Hui leaders who were committed to the development of a separate Sino-Muslim identity in China's north-west that had its own political representations. ${ }^{24}$ Prominent amongst these local leaders was Ma Qi, the Qing Dynasty loyalist military commander of Xining. Eventually appointed as governor by the Republican government, leadership of Qinghai passed on his death in 1931 in name to his brother but increasingly in fact to his son, Ma Bufang, who eventually replaced his uncle formally and led the province until 1949. Ma Bufang established essentially a separate, and Islamic, state-within-a-state in Qinghai under the Republic. He relied heavily on the Hui and Salar, recruiting military officers almost exclusively from Hualong and Xunhua counties (excluding Tibetans and Mongols from his army) and civilian officials from Ledu and Minhe counties ${ }^{25}$ While he was restrained in his opposition to Han Chinese generally, he was virulently anti-communist, and undertook a campaign of ethnic cleansing amongst the Tibetans in the north-east and eastern fringes of the province. $^{26}$

Qinghai was then in 1949 already a site of considerable contestation, and presented some particularly difficult political problems. In the first place the CCP had only a small and limited organization in the province. ${ }^{27}$ Moreover, the new regime underestimated the extent of opposition to Beijing, not only from the Islamic Hui and Salars, but also from the Tibetans. They mistakenly believed the Tibetans would welcome the CCP because it had defeated Ma Bufang. In the event, sporadic armed resistance continued throughout most of the $1950 \mathrm{~s}^{28}$

The strategy for the rapid development of Qinghai, adopted at the provincial CCP Congress in 1956, was to establish an industrial base in Xining, to open up the Qaidam Basin for extraction industries, and essentially to change the population mix through expansion both there and in the north-eastern corner of the province with massive migration from the eastern provinces. Some 176,000 people were brought into Qinghai during 1956 alone, and altogether more than 700,000 (or a third of the then provincial population) were migrated in during 1956-59. ${ }^{29}$

24. Jonathan Lipman, Familiar Strangers: A History of Muslims in Northwest China (Seattle: University of Washington Press, 1997). M. Hunsberger, "Ma Pu-fang in Chinghai province," PhD dissertation, Temple University, 1978, pp. 31ff details the politics that led to the establishment of Qinghai province.

25. Yang Xiaoping, Ma Bufang jiazu de xingshuai (The Rise and Fall of the Ma Bufang Clan) (Xining: Qinghai renmin chubanshe, 1986); Chen Binyuan, Ma Bufang jiazu tongzhi Qinghai sishi nian (The Ma Bufang Clan's 40 Years of Rule in Qinghai) (Xining: Qinghai renmin chubanshe, 1986, revised ed.).

26. Cui Yonghong (ed.), Ma Bufang zai Qinghai 1931-1949 (Xining: Qinghai renmin chubanshe, 1994), pp. 71ff.

27. There were 3,121 CCP members in Qinghai in 1954, in Qinghai ribao, 23 September 1954 , p. 1.

28. Chen Yufeng, Contemporary China's Qinghai, Vol. 1, pp. 46-50; Zhang Pu, Jia Dawu and Guo Jing, Dangdai Qinghai jianshi (Brief History of Contemporary Qinghai) (Beijing: Dangdai Zhongguo chubanshe, 1996), p. 149-166.

29. Sangjiejia (ed.), Qinghai baike quanshu (Qinghai Encyclopedia) (Beijing: Zhongguo baike quanshu chubanshe, 1998), p. 42. 
Through reclaiming wasteland and opening up new farmland the goal was to have 10 million people in Qinghai by $1967 .^{30}$

The plan for migration-led development went badly awry from the start. Already in 1956 as the policy was being announced publicly it was acknowledged that the migrants from the east were often reluctant to settle. Conditions were far from ideal and far from what they had been led to expect. Many of the migrants left the land and either returned to their previous homes or streamed into Xining. ${ }^{31}$ There was also considerable resistance from the local indigenous peoples, regardless of nationality, which was exacerbated by the CCP's campaigns for rural socialization that were being implemented simultaneously. In the middle of 1958, two different movements of resistance joined forces. Han Yimu, a Salar and former soldier with Ma Bufang who had evaded capture in 1952, raised the flag of revolt in Xunhua, as did the Tibetans in pastoral areas affected by collectivization. ${ }^{32}$

Having put down the attempted rebellion, the CCP's political response was to push on with the Great Leap Forward and to increase migration and land reclamation still further during 1959 and 1960, under the slogans of "take reclamation as the key link" and "turn the pastoral area into an important agricultural base." The attempt proved even more disastrous: Qinghai's altitude and climate meant that pastures frequently could not support crop production and were simply turned into wasteland. ${ }^{33}$ This time alienating the local indigenous peoples was a lesser problem. Agricultural and industrial production in Qinghai declined dramatically and there was a massive famine that resulted in a death rate in excess of four per thousand in 1960 (only Guizhou and Anhui suffered more as a result of the Great Leap ${ }^{34}$ ) and the exodus from the province of some 570,000 people during $1960-63 .{ }^{35}$

The failure of mass migration to achieve the goal of a measure of social control, and indeed having exacerbated the situation, led the provincial leadership to more straightforward measures in the early 1960s. It carried out a series of localized terror campaigns that resulted in large numbers of local leaders, especially Hui, Salar and Tibetans, being sent to "Reform through Labour" camps for political crimes, and often merely on suspicion of opposition to the regime. ${ }^{36}$ Essentially assimilationist policies were pursued, and almost all local activity that could be associated with specific minority nationalities was at first discouraged and then in the Cultural Revolution not allowed at all. Education, for example, was now to be conducted exclusively in Modern

30. Chen Yufeng, Contemporary China's Qinghai, Vol. 1, p. 85.

31. Henry G Schwarz, "Chinese migration to northwest China and Inner Mongolia, 1949-1959," The China Quarterly, No.16 (1963), p. 68.

32. Chen Yufeng, Contemporary China's Qinghai, Vol. 1, p. 92; Zhang, Jia and Guo, Brief History, p. 150.

33. Chen Yufeng, Contemporary China's Qinghai, Vol. 1, p. 89.

34. Dali L. Yang, Calamity and Reform in China (Stanford: Stanford University Press, 1996), pp. 33ff.

35. Sangjiejia, Qinghai Encyclopedia, p. 42.

36. Zhang, Jia and Guo, Brief History, pp. 166-170. 
Standard Chinese, with no allowance made, at least officially, for minority nationality languages. "Re"-settlement programmes for nomads were introduced together with continued land use that discriminated against pastoralists. Places of religious worship were heavily restricted, and later were closed altogether.

Despite the failures of the Great Leap, migration and the industrial development of Qinghai remained on the CCP's agenda throughout the era of the Cultural Revolution. This time, however, the emphasis was on the movement of whole industrial plants as part of the PRC's Third Front strategy of defence industrialization, ${ }^{37}$ though the strategy was no more successful. While industrialization continued in the Qaidam Basin, some 45 enterprises and their staff were moved to the Xining area alone, mainly from Shanghai and Shenyang. ${ }^{38}$ On paper the investment was impressive: some 2 billion yuan in fixed assets was invested across the provincial economy in this way. Unfortunately, the costs of production and transport were also high and the returns to the economy were low. The investment produced only a total increase in industrial output of 700 million yuan during $1965-76 .{ }^{39}$ Again, migration from China's east was largely unsuccessful in attracting permanent settlers. While there was significant in-migration during the Cultural Revolution, at the rate of 100-150,000 people a year, it was for the most part balanced by the numbers of those leaving over the same period. ${ }^{40}$

In the early 1980s the legacy of the Cultural Revolution in Qinghai rapidly came under criticism as PRC politics moved to embrace polices of reform and openness. In particular, the repression of national minorities during the late 1950s, the early 1960s and throughout the Cultural Revolution was denounced as "leftist excess" and those who had been imprisoned without having been directly involved in the earlier attempted uprisings were cleared of criminal accusations and released back into their communities. ${ }^{41}$ At the same time, considerably greater freedom of local cultural and religious expression was once again permitted, and even to some extent encouraged, throughout the province. If slowly at first, mosques, temples and monasteries were re-opened and revived. Starting in 1982 a new system of minority nationality education was introduced, where instruction was undertaken in the specific language of each nationality, though Modern Standard Chinese was also learnt. By 1985, there were 15 such colleges, 49 secondary schools and 1,423 primary schools, with the majority in Tibetan areas. Six women-only secondary schools were also established to meet the demands of local Muslims in Hui and Salar areas for gender separation in education. ${ }^{42}$

The economic legacy of the Cultural Revolution in Qinghai was a

37. Barry Naughton, "The Third Front: defence industrialization in the Chinese interior," The China Quarterly, No. 115 (September 1988), p. 351.

38. Zhang, Jia and Guo, Brief History, p. 214.

39. Chen Yufeng, Contemporary China's Qinghai, Vol. 1, p. 104.

40. Qinghai tongji nianjian 2001, p. 35.

41. Zhang, Jia and Guo, Brief History, p. 261.

42. Chen Yufeng, Contemporary China's Qinghai, Vol. 2, p. 335. 
series of not very productive industrial enterprises and a massive and increasing debt in government expenditure. All but a few of the province's enterprises looked likely to suffer terminally from the weakness of the provincial infrastructure, including a poor education system, and the lack of adequate communications with the rest of the PRC. In most cases production costs were too high to justify any activity economically. In addition, the high factor costs and the lack of appropriate infrastructure were to prove a massive disincentive to external involvement. Remarkably, no joint ventures involving foreign equity were established in Qinghai at all during the 1980s. ${ }^{43}$ Under these circumstances, the poor performance of the provincial economy during the first two decades of the reform era is no surprise.

\section{Opening Up the West}

The need for a new development strategy in Qinghai under the PRC's new (Tenth) Five-year Plan (for economic and social development) scheduled to be introduced in 2001 was acute. Quite apart from its poor economic performance during the 1980s and 1990s, in 2000 alone industrial output had fallen by 4 per cent on the previous year. ${ }^{44}$ In his 2001 Government Work Report the provincial governor emphasized the extent of crisis:

... the foundations of agriculture and animal husbandry are fragile, the process of industrialization is slow, the level of development of the secondary and tertiary sectors is comparatively low, there are few new economic growth points, and there are no reserves for further economic development [moreover] the provincial budget has a serious problem, with its increasing revenue not keeping pace with expenditure on a grand scale, so that there are many debts everywhere. ${ }^{45}$

Unremarkably, in the light of such comments, the provincial leadership's response included a plea for central government financial assistance for the Qinghai current account, which Beijing has continued to support. ${ }^{46}$ However, more fundamental has been the change in the province's strategy that has seen a commitment to a more gradual approach to development that encourages environmental sustainability, the improvement of the province's internal infrastructure, and the establishment of good communication links with the rest of the PRC. ${ }^{47}$ By the end of 2001

43. Barnett, China's Far West, p. 312.

44. Zhai Songtia, Qinghai 2002 Economic Blue Book Analysis, p. 328.

45. Zhao Leji, "Zhengfu gongzuo baogao" ("Government work report"), in Qinghai ribao, 27 January 2002, p. 1.

46. In 2001, central government provided just over $80 \%$ of the provincial government's budget, including 5 billion yuan for general expenditure, 3 billion yuan earmarked funds for the minority nationalities' areas, and some 3 billion yuan as salary supplementation to employees of the party-state.

47. "Qinghai sheng guomin jingji he shehui fazhan shiwu jihua gangyao" ("Outline of Qinghai province's five-year economic and social development plan for the national economy"), 10 January 2001, and Zhao Leji "Guanyu Qinghai sheng guomin jingji he shehui fazhan shiwu jihua gangyao de baogao" ("Report on the outline of Qinghai province's 
the central government had already committed 20 billion yuan in support of provincial infrastructure projects to these and other ends.

It seems likely that some of the planning for this change of direction and rhetoric was already under way before 2000, although these were not made public until after January 2000 and the more formal announcement of the programme to Open Up the West. Work had, for example, already started on some specific projects such as the Xining-Lanzhou expressway beforehand. Also, some of the principles of Qinghai's 1950's development strategy had already been long abandoned. Most notably there had been some understanding of the need for an approach based on principles of sustainable development already in the mid-1980s. A new population policy was adopted in 1986, when the programme of attempting to attract eastern province migrants to Qinghai was finally abandoned. Since that time, the growth in Qinghai's population has been tightly controlled, with Han Chinese subject to a one-child policy and minority nationalities limited to no more than two children. ${ }^{48}$ As a result, population growth in Qinghai has been remarkably constant since 1990 at around 12-14 per cent a year. ${ }^{49}$

Nevertheless, the extent of change in Qinghai's development outlook is at its greatest in the contrast between the emphasis until 2000 on mineral extraction from the Qaidam Basin, and the new catch-phrase (coined by Jiang Zemin) to "Open Up the West through rebuilding a green west." The provincial leadership has embraced the concepts of ecology and environmental sustainability, which are now the starting point not only for the new Five-year Plan but also in many specific policy areas. ${ }^{50}$ More narrowly, there have been two distinct aspects to the new programme of "re-greening." One has been the creation of environmental protection areas, the other a large-scale programme of farmland retirement, pastoral restoration and afforestation.

Presumably the recent water shortages on the Huang River and floods on the Chang have drawn the attention of Beijing to potential problems in these river systems at their source. ${ }^{51}$ Certainly there has been cause for concern: in a recent survey it was found that about half the lakes to be found in the Huang River's source catchment area had dried up. ${ }^{52}$ The response by the provincial government has been the creation of a Three

footnote continued

five-year economic and social development plan for the national economy"), 10 January 2001, both in Qinghai tongji nianjian 2001, special notes, p. 36 and p. 17 respectively.

48. Zhongguo renkou: Qinghai fence (China's Population: Qinghai Volume) (Beijing: Zhongguo caizheng jingji chubanshe, 1989), p. 213; Sangjiejia, Qinghai Encyclopedia, p. 43.

49. Qinghai tongji nianjian 2001, p. 33.

50. For example, with respect to the development of hydroelectric power stations in "Wosheng jiang toujuzi jiakuai shuili jianshe" ("The province will invest to speed up water resources construction"), Qinghai ribao, 13 May 2001, p. 1.

51. Wang Ying, "State focuses on green mapping," China Daily, 10 March 2001.

52. "Laizi quanguo de 50 wei zhuanjia yunji Xining: gongshang baohu Changjiangyuan shengtai huanjing de daji" ("Fifty experts from the whole country meet in Xining: discuss a major programme for protecting the ecosystem of the Chang River source"), Qinghai ribao, 11 October 2001, p. 2. 
Rivers Sources Preservation Area of 220,000 square kilometres across Yushu and Guoluo, the locations of the sources of the Huang River, Chang River and Lancang River, where land usage is to be more closely regulated. Similarly, in response to studies that showed increased salinization on the shores of Lake Qinghai through over-cultivation, the provincial government established a Lake Qinghai Environmental Protection Area that severely limits agricultural production in the area. ${ }^{53}$

The change in policy to encourage the return of farmland to pasture and afforestation is even more remarkable because of its associations with the contest for political space in Qinghai. Though in most cases the transformation of pasture to farmland was almost certainly only ever marginal where indeed it was not actually economically counter-productive, the practice continued as part of the attempted population expansion, even after the policy of mass migration ended. While the Han Chinese and the Hui are predominantly agriculturalists, the pastoralists are either Tibetan or Mongol. Inappropriate land usage and management by 2000 had resulted in widespread soil erosion, desertification and the reduction of water resources, as well as severe declines in average livestock sizes. ${ }^{54}$

The provincial government has developed and started to implement a "Provincial ecology environmental construction plan" that focuses on farmland retirement and afforestation. ${ }^{55}$ In 2000 and 2001, 500,000 $\mathrm{mu}$ of farmland was returned to forest and grassland in an experimental 16 counties. ${ }^{56}$ From 2002 it is planned to plant 2.27 million $m u$ to trees and grass in the Qaidam Basin (where desertification has been most severe) and to retire a further 1.8 million $m u$ of farmland to forest and grassland. ${ }^{57} \mathrm{~A}$ massive afforestation programme has been adopted, not least because it has been calculated that Qinghai lost about 3 million mu of trees between 1911 and 2000, a period in which farmland increased from 3.4 to 8 million $m u$. To manage this programme, the Bureau of Forestry, previously under the Provincial Agricultural and Forestry Office, has become a provincial department in its own right. ${ }^{58}$

The greening of Qinghai in these ways has received financial support from the central government as one of the ten large-scale infrastructure projects identified by the State Council as part of the original proposal to develop the western region at the beginning of $2000 .{ }^{59}$ Two other

53. "Qinghai jinzhi zai Changjiang Huanghe yuantou qu fangmu" ("Qinghai prohibits grazing at the sources of the Huang River and the Chang River"), in www.qhnews.com, 17 January 2002.

54. Zhang Shengjie and An Shiyuan, "Shengtai huanjing baohu yu zhili" ("Environmental protection and management of the ecology"), in Hu Yongke (ed.), Zhongguo xibu gailan: Qinghai (A Survey of China's West: Qinghai) (Beijing, Minzu chubanshe, 2000), p. 133.

55. Zhai Songtian, 2002 Qinghai 2002 Economic Blue Book Analysis, p. 228.

56. Wang Baoping, "Qinghai tuigeng huanlin quanmian pukai shengtai huanjinhua dedao kongzhi" ("Qinghai has started farmland retirement projects on all fronts"), Xining wanbao (Xining Evening News), 20 January 2002, p. 1.

57. Shen Weizu, "The policy of returning farmland to forest and grassland is to be practiced in 31 counties in Qinghai this year," Xihai dushi bao (Western City News), p. 1.

58. Interview with Wei Zhenduo, Senior Forestry Engineer, Provincial Forestry Department, Xining, 28 December 2001.

59. Interview with Zang Peiyan, in Beijing Review, 29 May 2000. 
large-scale projects in Qinghai were also included in that initial list: the construction of a natural gas pipeline from Sebei to Xining and then to Lanzhou; and the development of a large-scale potassic fertilizer plant in the Qaidam Basin. The extension of the railway from Golmud to Lhasa - which would then provide communications within the rest of Qinghai, as well as linking the Tibet Autonomous Region with the PRC rail network - was a third major project added later in the year. ${ }^{60}$ These are all major projects involving not only significant capital investment but also the large-scale mobilization of human and other resources. The construction of the new railway from Golmud to Lhasa, for example, is estimated at current prices to cost in the region of 30 billion yuan, or about US\$3.6 billion, and will be a major feat of engineering, not least because the track will cross large stretches of permafrost and wetlands. ${ }^{61}$

As with these very large projects, other smaller projects have been designed to improve Qinghai's internal infrastructure and its integration with the rest of the PRC. The provincial government has established a special office to attract investment to Qinghai from elsewhere in the PRC and internationally. ${ }^{62}$ As already noted, the Xining-Lanzhou expressway had started construction before the public adoption of the new western region development strategy. The entire road opened in January 2003, but the 35 kilometres from Xining to Ping'an county, providing a link to the provincial airport, was opened in October 2001. ${ }^{63}$ While this key link with the rest of the PRC has clearly been given high priority, funds have also been provided by the provincial government to local authorities to aid the development of paved roads within Qinghai. Some 171 million yuan was allocated for 2001 and 2002 as aid to encourage the construction of paved roads linking all the district centres and county towns. ${ }^{64}$ While there has clearly been an emphasis on transport and physical means of communication, new technology has also not been omitted from consideration. The provincial government established its own website in 2001 , if somewhat belatedly by the standards of provinces in the rest of the PRC, and has highlighted the need to develop widespread internet access across the province. ${ }^{65}$

Education has been included as part of the infrastructure that needs improving, with concerns about both quantity and quality. Only the Tibet Autonomous Region has worse rates of primary school participation, and

60. "State Council notice on implementing policies and measures to develop west China," New China News Agency Report, Beijing, 27 December 2000.

61. "Tibet railway breaks new ground," Renmin ribao (People's Daily), 8 November 2001.

62. "20 xiang hetong zai Xining qianding jiazhi 23 yi yuan" (" 20 contracts signed in Xining: value 230 million”), Qinghai ribao, 30 July 2001, p. 1.

63. "Pingxi gaosu gonglu feijichang duan yi kaifang" ("Airport section of Ping'an-Xining expressway open to traffic"), Qinghai ribao, 2 October 2001, p. 1.

64. "Guojia touzi 17.1 yi yuan yongyu wosheng daolu jianshe" ("State invests 1.71 billion yuan in provincial road construction"), Qinghai ribao, 26 October 2001, p. 1.

65. Jing Hui (ed.), 2002 nian Qinghai shehui lanpishu shehui xingshi fence yи уисе (Qinghai 2002 Society Blue Book Analysis and Forecast of Social Conditions, 2002) (Xining: Qinghai renmin chubanshe, 2002), p. 169; Zhang Fayu "Wangluo jingji dui xibu kaifa de qishi" ("The revelation of the internet economy in the opening of the western region"), Qinghai shehui kexue (Qinghai Social Sciences), No. 4 (2001), p. 50. 
both childhood and adult literacy, and Qinghai is far beneath the PRC averages in all those categories. There is concern about the quality of education being provided to those who do attend the formal education system, as well as about the tendency for anyone who does succeed in education to leave the province. Additional investment has been provided for school education, so that by the end of 2001 there were 5,180 schools, of which 1,122 were minority nationality schools, with 1.3 million students (about a quarter of the total provincial population). In order to improve the technical proficiency of the local workforce, Qinghai has also been permitted by the central government to have the highest enrolment rate of students proceeding to tertiary education from the school system, at 80 per cent. ${ }^{66}$

Continued development of Qinghai's established industries in salts, hydroelectricity, petrol and natural gas, and non-ferrous metals production has not been completely abandoned. Indeed, in some cases, as with potash development and the building of a natural gas pipeline, there have been commitments to further development. On the other hand, in some industries and enterprises there has been a clear recognition that there is no future for continued production. In Minhe county, for example, where government revenue has been almost totally derived from the local ferrosilicon industry, there has for some time been a recognition that the PRC's entry into WTO, outdated local technology, and high production and transport costs spells the end for the local industry, which could previously hardly withstand the competition within the PRC. ${ }^{67}$

New areas highlighted for expansion include tourism, herbal medicines and township (light) enterprises. ${ }^{68}$ However, all of these are likely to remain relatively small-scale, not least because of the climate, the fragility of the environment and poor internal communications within the province. Tourism is a good example of the problems facing a superficially attractive new industry. Local labour is cheap, the Qinghai scenery is indeed dramatic, and the plateau beyond the north-east corner of the province contains not only Lake Qinghai but also some of the highest mountains in the world. "Safari trips" to the source of the Chang are frequently advertised in Hong Kong. Even in the north-east corner, tourists can be attracted through the presentation of the spectacle of the ethnic mix, including, for example, various monasteries and the birthplace of the Dalai Lama. ${ }^{69}$ In this case the difficulties are not so much transport to Qinghai or even accommodation in Xining, as the difficulties of moving around the province, including restrictions in protected areas,

66. Interview with Li Weiheng, Deputy Head, Qinghai Department of Education, Xining, 30 July 2002.

67. Interview with Mou Fucai, Deputy Head, Minhe County People's Government, Minhe, 2 October 2001.

68. Zhai Songtia, 2002 Qinghai 2002 Economic Blue Book Analysis, pp. 219, 238 and 248 provides plans for the development of each new industry.

69. Interview with Ma Xiangdong, Deputy Head, Ping' an County People's Government, Ping'an, 1 August 2002. 
and a climate that restricts the tourist season from June to mid-September, all of which ensures that income from tourism is likely to remain limited.

\section{Impact and Reception}

Some commentators outside the PRC have regarded the campaign to Open Up the West as delivering more in rhetoric than in hard resources. ${ }^{70}$ This is clearly not the case for Qinghai, even though there remains a rhetorical dimension to change. While it can be argued that some of the expenditure committed since the beginning of 2000 would have been supplied anyway, both because of already planned projects and because of the need to maintain provincial government expenditure, it is also the case that the strategic redirection has provided Qinghai with additional resources it would not otherwise have received. At the same time, the rhetoric of change has not been negligible in assisting the party-state to adjust, as the provincial leadership attempts to persuade it and indeed the local population to abandon policies and practices developed over the previous four decades.

Reactions within Qinghai to the new strategy have been varied, as might be expected, ranging from enthusiasm and somewhat unrealistic optimism, through a more measured scepticism to frank cynicism and fear for the consequences of change. At one extreme some officials in the party-state still seem to articulate a stated belief that "the better times are just around the corner" despite the evidence of provincial government work reports, and even if the corner is now a 20 -year wait rather than a near instant tomorrow. There are, for example, expectations of external investment, of jobs to aid unemployment, of a narrowing of the wealth gap with China's east, of an improved environment, and that Qinghai will not always require subsidy from the PRC budget. ${ }^{71}$

Equally, outside the party-state, and particularly among many non-Han Chinese communities, there has been a considerable and positive response to change. Every minority nationality has seen a marked cultural and economic revival since 1999, though necessarily reactions have been far from uniform. Tibetan pastoralists have reacted positively to the changes in policies and practices on land usage. Hui and Salar traders and restaurateurs have proliferated across the province, and many of the province's larger private economic concerns are those that have originated with Salar from Xunhua, and Hui from Hualong and Minhe.

At the same time, the project to Open Up Qinghai has not been without its more sceptical and cynical reactions. As one TV journalist commented:

China's west is divided into two parts. One is the west with Chongqing at its centre. The other centres on Xi'an. The former has money and is looking for development

70. See, for example: Willy Wo-Lap Lam, "China's hard sell in the mild, mild west," CNN, 29 May 2001.

71. These were the most frequently mentioned in interviews with 27 officials of the party-state interviewed in Qinghai during 2001-2003. 
projects, the latter has projects and is looking for money [and] it's a shame some experts on China's west just came to visit Qinghai for one or two weeks and then began to make reports and draw up plans. None of them is doing detailed on-the-spot large-scale study. ${ }^{72}$

A leading cadre from a provincial government department indicated they thought the new policy would only "increase people's tendency to expect, depend on and beg for the state's support" while another thought "in the end the eastern enterprises may benefit more from the development of Qinghai's infrastructure" than the province itself.

Most negatively, the new direction in policy has been greeted by concerns that the new pressures for change threaten local culture. In the words of one Xining-based researcher: "If is not handled with care, the western development strategy will cause complaints from local ethnic minorities who fear that they will probably be assimilated and their interests invaded."73 Or, as a Tibetan journalist commented when asked his view of the impact of the new western development strategy on Qinghai, "local people are in great danger of losing their ethnic culture, and it will be difficult to reconstruct moral values." ${ }^{, 74}$

Interestingly, this perception of a threat to culture and civilization is regarded as a matter of concern not just for and by Qinghai's minority nationalities, but also for and by the Han Chinese. One local academic warned that while the new direction in Qinghai's development was desirable, "it will also have its harmful impacts: there will be a rise in corruption, moral value in certain area of the society will degenerate, pollution will become more serious." ${ }^{25}$ Another, in discussing the impact of WTO entry as well as the development strategy on Qinghai, commented that they would result in a homogenizing pressure for reform that would threaten Chinese civilization:

To some degree we should be grateful for such pressure. But as a long-established civilized country, it is horrible to lose one's civilization. Such opinion should not be seen as nationalism or national sentiment. It should be seen as an appropriate feeling for every Chinese. Therefore, it has become an urgent matter to explore the legacy of native cultural resources, to make full use of or to preserve native cultural resources. $^{76}$

These comments about cultures and civilizations under threat lead back once again to the issue of contestation, in particular where different ideas of civilization and different ideas of Qinghai as a place are concerned. Of course, there is no necessary conflict, or at least no necessary irreconcilable conflict, between cultures and communities on either of these matters. There are after all Hui and Salar businessmen who have flourished on a large scale in Qinghai under the new development strategy, and who have been lauded by both the provincial party-state and

72. Zhao Haining, Editor, Western Development television series, Qinghai Satellite TV Station, interview, Xining, 22 November 2001.

73. Interview, nationalities researcher, Xining, 1 October 2001.

74. Interview, journalist, Xining, 27 May 2002.

75. Interview, historian, Xining, 23 May 2002.

76. Interview, lawyer, Xining, 2 May 2002. 
their own local communities in the process. ${ }^{77}$ In Tongren the increased ability for different nationalities to engage in economic and cultural activities that they regard as appropriate has meant that the county town has once again become tri-partite with separate centres for the Chinese, the Muslims (Hui and Salar) and the Tibetans.

All the same, there are clear areas of interaction where different ideas of life-style and civilization do lead to resistance, opposition and sometimes even conflict. A written script was created for the Salar language in the early 1980s by the Qinghai Nationalities Institute. This development was not appreciated by the Salar and the script was just not used: they prefer to speak in their own Salar language but to write in Chinese for secular activities and in Arabic for religious purposes. Participation in primary school education in Qinghai is particularly low for the minority nationalities, but this is not necessarily because they do not value education. On the contrary the issue is often that they would prefer a different kind of education from that offered in the state system. Many Hui and Salar are unwilling to send their daughters to state schools, not least because they do not want their daughters educated in mixed sex classes, and in general regardless of gender they would prefer to send their children to the religious schools attached to local mosques rather than to state primary schools. Throughout the predominantly Islamic counties of Hualong and Xunhua, for example, it is common to see slogans on walls exhorting the local population to send their children to state primary schools: "If you want your children to have a tomorrow, send both the girls and boys to school today!"

Similarly there are likely to be conflicts that emerge over land usage and patterns of settlement. Farmland retirement has been advocated by the provincial leadership on grounds of environmental sustainability and economic efficiency, without apparent regard to the pastoral practices of the Tibetans and Mongols. Indeed, some of those who have advocated farmland retirement have also criticized the herdsman, in the words of one environmentalist, for being "responsible for the deterioration of the ecology of the grassland, driven by the lure of more cash, and increasing the uncontrolled number of animals" who then proceeded "to eat the grass roots and not permit the grasslands to revive."

In addition to the conflict over land usage there is also a clash over the provincial government's continued policy of settling nomadic herdsmen. The provincial government's goal is to settle all nomads by 2011, claiming to have completed the process experimentally in Hainan district by the end of $2001 .^{79}$ The point, according to one provincial official, is

77. For example, two of Qinghai's wealthiest entrepreneurs: Ma Yisihake (Yitzhak) of the Xuezhou Woollen Products Group, a Salar from Xunhua county, who heads Qinghai's largest private enterprise; and Shi Guotai, a Hui from Hualong County who runs a multi-enterprise and real estate group now with its headquarters in Xining.

78. Interview with Wei Zhenduo, Senior Forestry Engineer, Provincial Forestry Department, Xining, 28 December 2001.

79. Wei Xingguo and Jing Fachang, "Hainan mumin quanbu shixian dingju" ("Hainan herdsmen now live in settlements"), Qinghai ribao, 28 January 2002, p. 1. 
that: "After the nomads settle, they have more protection from natural disasters and better access to social services. Living in one place has many advantages and no drawbacks." This is not necessarily a view shared by those who are being settled. According to one: "There's nothing I'd rather be than a herder. I don't like cities. I like riding horses over the grasslands." $" 80$

Nor for that matter is conflict confined to relations between the Han Chinese and the party-state on the one hand, and the minority nationalities on the other. Tensions remain between some of the communities in Qinghai and may even have been exacerbated by the differential impact of the processes of socio-economic change stimulated by the new development strategy. For example, as already noted, in Qinghai's development since the 1920s relations between the Hui and the Tibetans have been characterized more by competition than by co-operation. The new policy environment has seen the rapid emergence of more and more high profile Hui businesspeople, restaurateurs and petty traders throughout much of the province, with the small retail sector now widely regarded as a Hui domain. Long-term mistrust and the potential for short-term misunderstanding, especially in commercial transactions, has on several occasions been a potent mix leading to violence, as erupted in riots in Jianza during February 2003. ${ }^{81}$

\section{Managing Change}

While it would appear that the prospects for Qinghai's development have improved substantially with the call to Open Up the West there remains a need for caution and perspective in assessing its impact on the province. Despite the rhetoric of significant change and a desire to narrow the socio-economic differentials with the eastern seaboard of the PRC, there remains an underlying reality of economic underdevelopment and little prospect of the large-scale external investment that would be required to make a significant difference in line with aspirations. Qinghai has little industry, limited agricultural capacity, weak infrastructure and restricted communications with the world outside the province. It is also likely to be dependant on central government funding for the conceivable future.

Moreover, even were the major economic problems of development to prove amenable to solution the process of change management in Qinghai appears to have omitted an important part of the mix. In other provinciallevel jurisdictions during the 1990s the party-state attempted to manage some of the consequences of change in development strategy through appeals to new constructions of community and place. ${ }^{82}$ While such an

80. Leta Hong Fincher "Nomadic heritage going for a song," South China Morning Post, 2 August 2001.

81. Reuters report "Tibetans, Muslim Huis clash in China" 23 February 2003, http://edition.cnn.com/2003/WORLD/asiapcf/east/02/23/china.clash.reut/.

82. Tim Oakes, "China's provincial identities: reviving regionalism and reinventing 'Chineseness'," The Journal of Asian Studies, Vol. 59, No. 3 (August 2000), p. 667; and David 
initiative carried no guarantee of success, or even elite solidarity, as the cases of Jiangxi and Hubei demonstrated ${ }^{83}$ they were nevertheless generally seen as a necessary part of the process of reform, not least to legitimize change and to help people understand how they relate to it individually. Necessarily too provincial leaderships were concerned in this way to attempt to manage the probable revolution of rising expectations that often results from a dramatically changed development strategy.

Elsewhere in the PRC these cultural projects were included in planning for change, and funding set aside for their implementation. From the available evidence it would seem that nothing similar has as yet been attempted in Qinghai. A new and imposing provincial museum building has been built (it opened in 2001) with the help of a Japanese benefactor (Kojima) in the centre of Xining, yet its exhibits concentrate overwhelming on the history of Xining itself and of Chinese settlement.

Qinghai's lack of a cultural development strategy seems particularly short-sighted since there are quite clearly different ideas of the province that, while they may overlap and are not necessarily mutually exclusive, also do not coincide. Political contestation is certainly not as acute as it was in the 1950s, nor is resentment (of the Chinese state) as great as it was during the 1960s and 1970s. Nevertheless, the differences that separate Qinghai's various communities - particularly the indigenous and migrant Han Chinese, as well as the Tibetans, Hui, Mongols, Salar and $\mathrm{Tu}$ - cannot be assumed to be of no importance or to be subsumed by a common sense of purpose. Differences over land usage and tensions over trading, to take two already-noted examples, are likely to affect the province's longer-term prospects for economic development, quite apart from any equally likely adverse impact on inter-communal relations. Symptomatically, each community still retains its own icons and symbols, which may themselves be matters of contestation for others. Most obviously, the province's Republican-era warlord, Ma Bufang, remains very much alive in the public consciousness: as a hero for the Hui and Salar, and quite the opposite for other nationalities.

In comparison to other provincial-level jurisdictions, Qinghai's leadership is necessarily more restricted by the complex social environment in its ability to manage ideas of place and community. Moreover, the formulations of Chinese nationalism generally limit the extent and the ways that non Han Chinese voices are recognized, and the CCP has problems in dealing with ethnic or nationality difference other than as a

footnote continued

S. G. Goodman, "Structuring local identity," The China Quarterly, No. 172 (December 2002), p. 837.

83. Feng Chongyi, "Jiangxi in reform: the fear of exclusion and the search for a new identity," and Zhao Lingyun, "Hubei: rising abruptly over central China?" in Hans Hendrischke and Feng Chongyi (eds.), The Political Economy of China's Provinces: Comparative and Competitive Advantage (London: Routledge, 1999), pp. 249 and 155 respectively. 
function of economic development. ${ }^{84}$ As a result, the provincial partystate has clear difficulties in any attempt to go beyond its current focus on Qinghai as a Xining-centred area of expanding Chinese civilisation. ${ }^{85}$ A key question for the future of the province is then whether this conceptualization will remain acceptable to other ideas of place and community, especially as the latter grow in wealth and self-confidence.

84. For local examples, see: Ren Qizheng, "Lishi de jiaxiang" ("The false appearance of history"), Qinghai shehui kexue, No. (2001), p. 84; Zhang Liji and Gao Yongjiu, "Minzu zhijian wenhua chuanbo fangshi chutan" ("A preliminary exploration of the style of cultural dissemination amongst nationalities”), Qinghai shehui kexue, No. 6 (2001), p. 96.

85. See for example Cui Yonghong, Zhang Dezu and Du Changshun (eds.), Qinghai tongshi (A General History of Qinghai) (Xining: Qinghai renmin chubanshe, 1999). 
language, and chair of the department of the languages and cultures of China and Imner Asia, SOAS. He has published monographs on traditional Chisese poctics (1995), the history of Sinology (2001), and has edited a volume on censorship in modern and pre-modern China (Harrassowilz, 2003).

Johos Grtmpas was China specialist for The Guardian, 1983-2003, and first visited China in 1971 . He is now a rescarch associate at the Centre for Chinese Studies, School of Oriental and African Studies.

DAVID S. G. GOODMAN is professor of international studies at the Unjversity of Technology, Sydncy. His most recent publicatious include Social and Political Change in Revolutionary China (Rowman \& Littlefield, 2000) and (with Werner Draguhn) China's Communist Revolutions (Routledge, 2002). He is curlently complecing a social history of Qinghai Province under the Pcople's Republic of China.

RACIIEL HARRIS is a lecturer in ethnomusicology at SOAS, teaching the musics of Central Asia and China. Her book on the music of Sibe-Manchu will be published by OUP in June 2004. Her current research specialism is Uyghur music, especially politics, recorded music, identity and change.

HeIKE Holbig is a research fellow at the Institute of Asian Affairs, Hamburg, working in the field of domestic politics in the PRC. She trained in Chinese studies and economics at Heidelberg University and Beijing University. Recent publications in English include (with Robert Ash) China's Accession to the World Trade Organization. National and Intemational Perspectives (RoutledgeCurzon, 2002) and "The Party and Private Entrepreneurs in the PRC," Copenhagen Journal of Asian Studies, vol. 16 (November 2002).

JEESOON HONG is a post-doctoral research associate in the department of Sinology, JWG Universitàt Prankfurt. She specializes in modem Chinese literalure and her PhD dissertation entitled Gendered Modemism of Republican China: Lu Yin, Ling Shuhua and Zhang Ailing was presented in the department of Chinese studies, University of Cambridge. Her article, "The Chinese gentlewoman in the public gaze: Ling Shuhur in twentieth century's China and Britain" will be published in a forthcoming volume on Perceptions of Gentility in Chinese Literature and History (Stanford University Press)

LилАN Hong is a senior lecturer in the Chinese studies program at Monash University. Melbourne. A native of Sichuan, be started his research career into Chinese local politics as a research fellow at the Institute of Political Science of Sichuan Academy of Social Sciences (Chengdu). After finjshing his PhD at the Australian National University, he began focusing on central-local relations in post-Mao China and regional social, political and economic development in South-West China.

JUYCE K. KALLGREN is emeritus professor of political science at the University of California, Davis, research associate at the Instilutc of East Asian Studies (University of California, Berkeley) and chair of the U.S. Council on Security Cooperation in the Asia Pacific. 


\section{Instructions for contributors}

The China Quarterly welcomes the submission of manuscripts from siliolers, including postgraduate students, on all aspecls of conlemponsy China and fron all ponts of vicw, including those which deal with Jajwan and Overseas Chincse. Articles on Chira prior to 1949 are aiso weicome, particularly, but not exclusively, when these relate directly in contemprary China or to the history of the Chinese Communist Pany.

Articles should be submiticd in quintruplicate to the editorial oftice. They should normally not exceed 8,000 words in length; should be typed in double spacing on one side of the sheet only, with fnotnotes at the end; and should conform to the styling of The China Quarleriy (se below). An ubstract of 100-150 words should also be provided. Submission of a Dlanuscript is taken to imply that it has not previously been published in any form (including non-copyrighted working papers) and that it is not currenuly being considered elsewhere.

The Chine Quarterly is published by Cambridge University Press on behalf of the School of Oriental and Africun Siudies, Univcrsity of London, UK. The views expressed in articles are those of individual authons and do not necessarily represent the views of the Schonl.

Style

Romanuzalon and Chinese churacters

Pinym is used without tone/diacritical marks, cxccpt the following which should use the Wade-Giles systcm: names such as Chiang Kai-shek, Sun Yat-sen, Taipei and Kunnintang, names of individuals liviug ousside mainland China. Chinese characters must be provided for all Chinese verts und proper nuuns.

Cirations

Books:

(Chincse) Author, Chinese virle of book (Translation of Title) (Place nf Publication: Publisher of Book in. Chinese, date), pP.?

(Englisli) Author. Till of Buok (Pluce of Publiculion: Publisher, uate), pp. ?. Aricles:

(Edited volumes) Author of arricle, "Title of anticle," in Author (ed.), Title (Place of Publication: Publisher, date), pp. ?. [with tranklation of Chinese article and volume litles]

(Jounals) Author of article, "Tille of article," Journal Tille. Vol, ?. No. ? (year), pp. ?. Lwich uranslation of Clinese arlicile and joumul titles] Swbsequenr citarions:

Use ibid. to refer only to the immediately preceding reference or part of it; idem. and op. ciit. should nul be used. The shortened title system is used as follows

Books:

(Chincsc) Full name of author, Shortened Title, pp. ?

(English) Sumame, Shriened Tile, pp. ?

Arficies

(Chinese) Full name of author, "Shortened titlc of aricle," pp. ?.

(English) Surname, "Shortened title of artide." pp. ?.

[no mention of volume necessary]

A utore detuiled style sheet is available on request.

Copyright

It is a condition of publication un the Juurnul thut authors assign copyright to the School of Uricntal and Africun Siudies. This ensures that requests from third paries 10 reproduce articles are handled efficiently and consistently and will also allow the aricle tn be as widely disseminated as possible. In assigning copyright, Authors may use their own material in other publications provided thut the Journal is acknowledged as the original place of publicalion, and C'umbridge University I'ress is notified in writing und in advance.

CAMBRIDGE UNTVERSITY PRESS

The Edinburgh Building. Cambridge CB2 2RU, United Kinguom

40 West $20^{\text {in }}$ Street. New York, NY I001 ] -42] I, USA

477 Williamstown Road, Dor Melboume, VIC 3207. Auscralia

Ruiz de Alarcón 13, 28014 Madrid, Spain 


\title{
The China Quarterly
}

Pubisished hy Cambridge University Press for the School of Oriental and African Siudies. University of London. UK.

The Edirorial office

School of Oriental und Africun Stucies, Thornhaugh Screet. Russell Square.

London WC1H OXG.

Tel. $+44(0) 2078984063$ or $+14(0) 2076372388$

Fax $+44(0) 2078984849$ or $+44(0) 2074363844$.

\begin{abstract}
Subscriptions
The China Quarterly (ISSN 0305-74I0) is published quanerly in March, June, September and December. The subscription price which includes electronic access and delivery by air wherc appropriatc (but excluding VAT) of volumes 177 to 180 in 2004 is $£ 95.00$ (US $\$ 155.00$ in USA, Canuda and Mexico) for instilutions; $\mathcal{E} 40.00$ (US $\$ 69.00$ ) for individuals ordering direct from the publishers and certifying that the joumal is for their personal 11se. Students can subscribe at 220 (US \$.3.5). Single parts are $\$ 24.00$ net (US $\$ 39.00$ in USA, Canada and Mexico) plus postagc. EU subscribers (outside the UK) who arc not registercd for VAT should udd VAT at their country's rate. VAT registered members should provide their VAT registration number. Japanese prices for institutions (jncluding ASP delivery) are available from Kinokuniya Company Lid, P.O. Box 55, Chitose, Tokyo 156, Japan.
\end{abstract}

Orders, which must be accompanicd by payment, may be sent 10 a bookseller, subscription agent or direct to the publisher: Curnbridge Universily Press. The Edinburgh Building. Shaftesbury Road, Cambridge CB2 2RU; or in the USA, Canada and Mexico: Cambridge University Press, 100 Bork Hill Drive, West Nyack, New York, 10994-2133. Application to mail an Perindicals Postage Rates is pending at New York, NY.

The current plus threc back volumey ure avuilable from Cambridge University Press.

Advertising

Adverisements are welcomed and rates will be quoted on request. Enquiries should be uddressed to Rebecca Curtis, Adverlising Promuler, Journals Group, Cambridge University Press, The Edinburgh Building. Shaftesbury Road, Cambridge CB2 2RU. UK. Tel +44 (0)1223 325757 Fax $+44(0) 1223$ 325801 .

\section{Copying}

This journal is registered with the Copyright Clearance Center, 222 Rosewood Drive, Danvers, MA 01923, USA. Organizations in the USA who are also registered with the C.C.C. may, cherefore copy material (beyond the limits permitted by sections 107 and 108 of U.S. Copyright law) subject is payment to the C.C.C of the per copy fee of $\$ 12.00$. This consent does not extest to nuultiple copying for promorional or cornmercial purposes. Code 0305-7410/03. ISI Tear Sheel Service, 3501 Market Street, Philadelphia, PA 19104. USA, is authorized to supply single copies of separate articles for private use only. Organizations authorized by the Copyright Licensing Agcncy may also copy material subject to the usual conditions. For all other use, permission should be sought frum Cambridge or from the Ameriean Branch of Cambridge University Press.

This journal is included in the Cambridge Ioumals Online Service which can be found at hatp://www.jnumals.cambridge.org. For further information on other Press vitles access http://www.cambridgc.org.

Schowl of Oriental and African Studies. University of London, 2004 ISSN 0305-7410

Printed in the United Kingdom by Infolype Lid, Oxfordshire 